with this body. The address closes on a note of encouragement to the younger generation of metallurgists, for whom the future holds in store a wealth of opportunity.

Mr. Harry Brearley's book makes exhilarating reading. His main thesis concerns the value of the judgment and vision of the workman-of the art as opposed to the science of steel-making. This idea is developed with the aid of some pertinent thrusts at the too highly scientific metallographer or chemist, who is apt to use a language which only the initiated can understand and to become unintelligible to those who dutifully read his reports. "There are complaints that what should be, or might be, a clearing house for difficulties is apt to degenerate into a priestcraft able to obscure a difficulty if not explain it."

Mr. Brearley has some hard things to say on the subject of the teaching of metallurgy and the comparative neglect of the process side of steel metallurgy. "And as what the schools call metallurgy turns out to be almost exclusively metallography, there is little wonder that the graduate student comes into the works with notions about the importance of this or that which are sadly out of balance. . . . As a supplement metallography is excellent: as a superseder of the older forms of observation and deduction it may not be so excellent-it may be misleading. What a man sees through a microscope is more of less, and his vision has been known to be thereby so limited that he misses what he is looking for, which has been apparent at the first glance to the man whose eye is informed by experience." This leads to views on technical education which are definitely constructive, and a very interesting and attractive suggestion is put forward for the teaching of steel metallurgy under industrial conditions.

Mr. Brearley's book is in part autobiographical, dealing with the author's early days as a cellarlad in a tool-steel furnace-an occupation he entered at the age of eleven or twelve-with the intimate details of the crucible process as practised in Sheffield in the 'eighties, and with his admiration for the skilled steel-melters with whom he came in contact. "The goodness of the craftsman is in his bones and beats with his blood. The same unruffled confidence, and modesty too, which unfolds itself in men like Faraday unfolds also in humbler workmen; and whilst in them uncouth expression might be mistaken and misunderstood, there are such men whose opinion, muttered in their sleep, is valuable beyond the calculated views of others. Amongst even steel-melters there are 'mute, inglorious Miltons'." $\quad$ L. B. H.

\title{
The Asiatic Society of Bengal
}

By Dr. L. L. Fermor, o.B.e.

$\mathrm{A}^{\mathrm{S}}$ the Asiatic Society of Bengal is arranging $A$ to celebrate on January 15 the one hundred and fiftieth anniversary of its foundation, a short account of its activities will be of interest.

The founder of the Society, Sir William Jones, a Puisne Judge of the Supreme Court at Fort William in Bengal, arrived in Calcutta in 1783. Sir William Jones, who was a distinguished scholar and linguist, soon noticed the want of an organised association as a drawback to progress, and with the co-operation of his friends held a meeting on January 15, 1784, at which thirty gentlemen representing the elite of the European community in Calcutta were present. Sir William Jones delivered a "Discourse on the Institution of a Society for enquiring into the History, civil and natural, the Antiquities, Arts, Sciences, and Literature of Asia" ; and as a result of this address it was resolved to establish a society under the name of the "Asiatick Society". The name adopted for the Society at the inaugural meeting was borne on the records until the close of the fourth decade of the nineteenth century.

In 1829, soon after the foundation-by Henry Thomas Colebrook, a former president of the Asiatic Society - of the Royal Asiatic Society of Great Britain and Ireland in London, and the affliation of the Literary Society of Bombay with that institution, a letter was received from the Royal Asiatic Society offering to the Asiatic Society in Calcutta the privilege of affiliation, and in this letter the Asiatic Society was for the first time designated as the "Asiatic Society of Bengal". The Society did not accept the affiliation or the change of title, but as the parent of all the Asiatic Societies extant it fitly retained its original name of The Asiatic Society. In 1832, also, when Mr. James Prinsep sought the sanction of the Society to use its name for the journal he was then about to start, the resolution used the words "Asiatic Society" only ; but the editor found it convenient to add a local designation and, in 1843 , when the journal became the property of the Society, the new name of Asiatic Society of Bengal had already become familiar and it was formally introduced into the code of by-laws published in 1851. This title has been used continuously since.

This detail concerning title has been deemed necessary because of the confusion that sometimes arises between the titles Asiatic Society of Bengal and Royal Asiatic Society of Great Britain and Ireland, and because it is not always realised that the Asiatic Society of Bengal is the parent and older body.

In his inaugural dissertation, Sir William Jones expounded the definition of the aims of the Society contained in the title of his address and his words have been paraphrased into: "The bounds of its investigations will be the geographical limits of Asia, and within these limits its enquiries 
will be extended to whatever is performed by Man or produced by Nature" ; and this sentence now serves as the motto of the Society.

At the second meeting of the Society it was decided to invite Warren Hastings, then GovernorGeneral of India, to accept the office of president of the Society. Hastings declined the honour on the grounds of his inability to devote sufficient attention to the work of the Society and for other reasons, and requested the permission of the Society to yield his pretensions to the gentleman whose genius planned the institution. Following this suggestion, Sir William Jones was elected the first president and held office until his demise in 1794.

The institution thus planned and founded has had a continuous existence down to the present and is still in active being. In 1884 the Society celebrated the centenary of its foundation and published a centenary review volume, in which is a full account of the past century's work of the Society. This volume contains first (Part I) a history of the Society, from which the foregoing details have been taken. Then comes in Part II a review of the literary activities of the Society, classified under archæology, history, literature, etc. From this section the reader will learn the outstanding part played by the Asiatic Society in the deciphering of inscriptions on stone and metal, (coins and pillars), and in texts on palm leaf and paper ; and in the discovery of the clues to ancient scripts, with resultant contributions to the history of ancient India. In this section outstanding names are Sir William Jones himself, Henry Thomas Colebrook (the founder of the Royal Asiatic Society), Horace Hayman Wilson (of the Medical Service of the East India Company, Assay Master of the Calcutta Mint and finally Boden professor of Sanskrit at Oxford), and James Prinsep (who succeeded Wilson as Assay Master).

Part III of the centenary volume summarises the researches in science published by the Society, classified under mathematical and physical sciences, including meteorology, geology, zoology, botany, geography, ethnology and chemistry. Amongst researches to which reference may be made are the Venerable Archdeacon Pratt's views on the importance of allowing for Himalayan attraction in determining the curvature of the arc of the meridian in Hindustan, Capt. J. T. Newbold's researches on the geology of Southern India, work on the correlation and classification of the Peninsular formations of India, particularly the researches of Thomas Oldham and W. T. Blanford, the work of Hugh Falconer and Proby Cautley and others upon the rich vertebrate fossil fauna of the Siwalik Hills, Brian Hodgson's studies of the bird and mammalian fauna of Nepal, Sikhim and Tibet, and the work of the "Indian Linnaeus", William Roxburgh, on the plants of the East. A rich field was tilled by a number of workers on the ethnology of the numerous tribes of India.
In the early days of the Society, the East India Company, the predecessor of the Crownin India, had no organised scientificservices, and thescopefor such a society as the AsiaticSociety in collecting, describing and classifying the natural history objects of India, particularly in the fields of geology, zoology, botany and ethnology was enormous; . and the Asiatic Researches, the first publication of the Society, and the volumes of the Journal of the Asiatic Society of Bengal, contain a great number of papers on aspects of the natural history of India. These activities led to the accumulation of a large quantity of specimens, in consequence of which the Asiatic Society was compelled to found its own museum. Ultimately, the increasing volume of material proved too great a tax on the resources of the Society, and negotiations were opened with the Government of India, which terminated in the establishment of the present Indian Museum, in accordance with Article XVII of 1866. The collections of the Asiatic Society of Bengal were then entrusted to the Indian Museum, which is administered by a board of trustees on which the Asiatio Society of Bengal was, and still is, represented. These collections were incorporated with the collections belonging to Government or made by Government departments, such as the Geological Survey of India, founded in 1851.

The formation of several Government scientific services, such as the Geological Survey of India, the Indian Meteorological Department, and the Botanical Survey of India, the Zoological Survey of India, and the Agricultural Research Institute at Poona, each department with its own journal or journals, now diverts to the respective publications a large number of papers that would formerly have been presented to the Asiatic Society of Bengal: In addition, the formation of specialist scientific societies, such as the Indian Chemical Society, the Indian Physical Society and the Mining and Geological Institute of India, affords an outlet for the papers of non-official workers in science, many of which in the past would have been offered to the Asiatic Society of Bengal. The consequence is that the number of papers in science offered to the Asiatic Society of Bengal has fallen during the fifty years now ending much below the figures of the past.

The Society has not, however, lost its importance to science. Apart from its historical rôle of parent and sponsor directly or indirectly of many of the scientific societies and Government scientific departments in India, the Society now undertakes the important duty of organising the Indian Science Congress Association, a body that plays in India a part analogous to that of the British Association in England, meeting annually in January at different centres in India. The Society not only acts as organiser and office to the Indian Science Congress Association but also publishes the annual volume of Proceedings of the Congress meetings.

In respect of science, therefore, the Asiatic Society of Bengal now plays the rôle of an 'elder 
body'. There is a general feeling that with the formation in India of an increasing number of specialist and local societies, and the resultant increasing tendency of sciences to work in isolution from one another, that a greater measure of co-ordination is required than is afforded by the annual meetings of the Indian Science Congress; the question of forming an Indian Academy of Sciences is consequently under discussion. One possible solution would be that the Asiatic Society of Bengal should occupy a position analogous to that of the Institute of France and become the parent body for not only an Indian Academy of Sciences, but also for an Indian Academy of Let.ters to ripresent the other side of the present activities of the Asiatic Society of Bengal and other groups of men of letters in India. Such a development, with perhaps a reversion of the title of the Society to "Asiatic Society" without the words "of Bengal", so as to remove the provincial sound, would seem to be the simplest solution to the problem and one that would well celebrate the hundred and fiftieth anniversary of the Asiatio Society, should this seem appropriate to the scientific workers of India as a whole. Such a development would also have the great advantage of preserving the liaison that still exists between science and letters in India.

\section{Economics of Nutrition}

$\mathrm{T}$ HE Council of the British Medical Association, having realised that the adequate nutrition of the population is a matter of national import. ance, appointed a committee in April 1933 "to determine the minimum weekly expenditure on foodstuffs which must bc incurred by families of varying size, if health and working capacity are to be maintained, and to construct specimen diets". The report of the committee was printed as a supplement to the British Medical Journal of November 25,1933 , which has now been reprinted.

The feature of the pamphlet is a series of sixteen carefully compiled diets suitable in quantity and variety for a single adult man, for children of various ages and families of different sizes. The quantities of the foodstuffs are calculated in accordance with the physiological standards and 'man value' of the families from Cathcart and Murray's figures. A family consisting of a man, a woman, and four children of the ages thirteen, ten, seven and four years, according to this standard has a man value of $4 \cdot 63$.

Stress is laid upon the kind of protein, whether it is of animal origin (first class), or of vegetable origin (second class). 'The infant's diet of milk consists of animal protein only, and it is advised that the change from tho infant's to the adult diet be gradual, with the maintenance of a high proportion of animal protein, and be not completed until the child is three to five years of age. The amount of animal protein is maintained at a high level (60-75 per cent of the total protein) at any rate until school age is past, as shown in the specimen diets, and may be continued at this level so long as the child is growing. Unfortunately, the introduction of animal protein adds to the cost of the diet and is not always practicable. It is recom. mended that the supply of protein for the child be from cheese, fish and minced meat. We may refer to diet No. 4 proposed for a child of one to two years. It is based upon a minimum of 1 pint of milk daily, which is looked upon as the maximum expenditure which is likely to be possible on this article of food. 'The weekly quantities are : milk 7 pints ; meat lb. ; fish $\frac{1}{1 b}$. ; butter $\frac{1}{8} \mathrm{lb}$.; flour 1 lb.; 'oatmeal $\frac{1}{6}$ lb.; sugar $\frac{1}{8} \mathrm{lb}$.; potatoes $1 \mathrm{lb}$.; $\frac{1}{2}$ lb. each of cabbage, turnips, carrots and tinned tomatoes. In this diet the proportion of animal protein is 71 per cent of the total protein and the calorie value is 1006 ; the child of this age corresponding to a man value of 0.3 .

Similar diets with proper first-class protein for older children of three to six years are given in Nos. 5 and 6 . In diets Nos. 7 and 8, for children of six to ten years, the milk is reduced to $\frac{1}{2}$ pint daily.

Diet No. 1 is an example of the bare ration without variety for an adult man and costs $\mathbf{5 8 . 2 5}$ pence weekly. With variety the cost is increased to 70.5 pence weekly. Diets 9-16 are family diets with one or more children of different ages, and the man cost of these diets is $76 \cdot 1-66.5$ pence weekly. The costs have been calculated from a special scale of prices ascertained by the British Medical Association. Another scale of lower prices gives those prevailing in Stockton.

So far as the diets are concerned, the variety and quantities are extraordinarily well chosen and could be universally adopted. We would eamestly recommend all schools and institutions to use these standards of quantities and regard them as the minimum, increasing the quantities of milk, meat, fish and $\mathrm{cgg}$ if funds permit. Children would thus be given a fair start in life. There is at present a tendency in school diets to restrict the supply of first class protein to a level inconsistent with the demands of growth betwcen the ages of fourteen and eighteen years.

A considerable proportion of the specimen diets consists of dairy produce, vegetables and fruits. The mincrals of the diet are thus amply provided. The supply of vitamins, especially of $\mathbf{A}$ and $D$, and $\mathrm{C}$ is regarded as sufficient from the quantities of milk, butter, eggs, cheese, liver, fish and vegetables. It is pointed out that whole cereals, beans, peas and lentils are the sourco of vitamin $B$, but some of the dicts do not contain any of these articles of food, and if included the weekly total of such foods is very small. No stress is laid upon the advantage of wholemeal bread in preference to white bread or flour, for the supply of 